Operative Dental Surgery 


\section{Operative \\ Dental Surgery}

J. J. MESSING, B.D.S. (Durham), F.D.S.R.C.S. (Eng.)

Reader and Honorary Consultant, Department of Conservative Dental Surgery, University College Dental School, London

and

G. E. RAY,F.D.S.R.C.S. (Eng.) 
(C) J. J. Messing and G. E. Ray 1972, 1982

Softcover reprint of the hardcover 1st edition 1972 978-0-333-31040-3

All rights reserved. No part of this publication may be reproduced or transmitted, in any form or by any means, without permission.

First edition published 1972 by

Henry Kimpton Publishers

Second edition published 1982 by

THE MACMILLAN PRESS LTD

London and Basingstoke

Companies and representatives throughout the world

ISBN 978-0-333-31041-0 ISBN 978-1-349-86078-4 (eBook)

DOI 10.1007/978-1-349-86078-4

Typeset in Great Britain by

STYLESET LIMITED · Salisbury

The paperback edition of the book is sold subject to the condition that it shall not, by way of trade or otherwise, be lent, resold, hired out, or otherwise circulated without the publisher's prior consent in any form of binding or cover other than that in which it is published and without a similar condition including this condition being imposed on the subsequent purchaser. 
This book is dedicated to the Dental School of University College, London, and to the memory of Alan Shefford, O.B.E.

Those of us who remember him best will never forget his stock phrases of which the following are examples:

' ... The foundations of surgery are based on anatomy, physiology and pathology.'

'. . Always look for the sparrows, not the Golden Crested Eagle.'

'... The most important instrument in the conservation kit is the sharpening stone.' 


\section{Contents}

Preface to the First Edition ix

Preface to the Second Edition

1 History Taking, Examination and Diagnosis 1

2 The Occlusion $\quad 8$

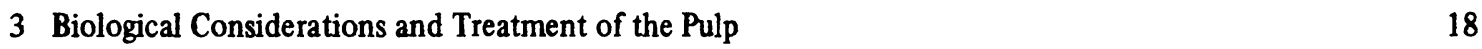

4 The Problem of Pain in Conservative Dentistry 22

5 Restoration Form $\quad 25$

6 Instruments and their Use $\quad 29$

7 The Control of Moisture in the Mouth 39

8 Temporary Restorations and Lining Materials $\quad 48$

9 Amalgam $\quad 54$

10 Aesthetic Plastic Restorative Materials 61

11 Composite Restorative Materials $\quad 68$

12 Gold $\quad 84$

13 Porcelain $\quad 86$

14 Cavity Preparation $\quad 90$

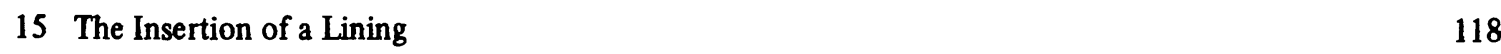

$\begin{array}{lr}16 \text { Matrices } & 120\end{array}$

17 Manipulation of Amalgam $\quad 123$

18 Impression Techniques $\quad 134$

19 The Fitting of a Gold Restoration 156 
20 Advanced Restorative Dentistry

21 The Crowning of Vital Teeth

22 The Three-quarter Crown

23 The Post-retained Crown

24 Temporary Crowns

25 Endodontics

26 The Bleaching of Pulpless Teeth 


\section{Preface to the First Edition}

The authors of this text have nearly thirty years of academic and general practice experience to guide them, and with this in mind it was thought that they could contribute a work of value to practitioners for reference, and for students, to supplement both lectures and practical studies. In order to achieve this goal much has been treated in note form, and particular sections such as materials, bridgework and precision attachments require reference to specialist texts. On the other hand more space has been devoted to techniques of restorative treatment, and to endodontia, in order to highlight some of the changes brought about through the introduction of new materials and instruments, and to emphasise the importance of looking repeatedly and objectively at our work in the light of the latest research.

As a departure from the conventional layout, the chapter on cavity preparation has been written to include all types of intra-coronal work, thus enabling students to make ready comparisons between the variations in procedure for each class of cavity.

Restorative procedures are then followed separately under appropriate headings in relation to the materials considered. Many erstwhile popular materials, such as cohesive gold, copper amalgam and inlay porcelain, have been omitted or only briefly mentioned, partly because there are already many sources available, and partly because of their dwin. dling popularity within the United Kingdom.

The bulk of the procedures described are taught at University College Hospital Dental School, but allowance has been made for the natural differences of opinion which inevitably arise, but such differences are on the whole slight and do not invalidate the basic principles underlying the work.
A few of the techniques mentioned are original, but the majority are not, and the authors wish to acknowledge their indebtedness to their teachers and colleagues from whom the subject matter contained in this book has been gleaned, though it would probably be right to acknowledge that we owe an even greater debt to those members of the public who have so trustingly looked to us for help over the years.

We also wish to acknowledge the generous assistance provided by the following: Miss Frances Ross, for typing the manuscript; Mr C. R. Day, for the photographic reproductions; Mr J. M. Perkins, for the illustrations; and Mr R. Sherman and the staff of his laboratory for the production of models to be used in making the photographic illustrations.

We wish also to thank the editors of the British Dental Journal, The Dental Practitioner and the Journal of the British Endodontic Society for permission to reproduce photographs and drawings, used previously in these journals, and also the Amalgamated Dental Company, Engelhard Industries Ltd, Dental \& Surgical Supplies and L. Porro Ltd for their invaluable help in supplying photographs and line drawings of their apparatus and instruments. Also the 3M Company for their permission to reproduce the tables of comparative physical properties, in the chapter on Composite Restorative Materials, and Mr J. W. McLean for the drawing and photographs of his alumina tube post crown technique.

In particular we owe our grateful thanks to Professor Prophet for his generous help in placing the facilities of the School at our disposal during the writing of this book. 


\section{Preface to the Second Edition}

Since 1972 when the first edition of this book was published, there have been immense strides in the technology and science of operative dental surgery. These developments and the great volume of research behind them have rendered obsolete much previously accepted dogma.

Thus the weeding out of some of the obsolescent techniques and their replacement has engendered considerable soul searching and I apologise to all who feel that their own invaluable contributions to dentistry have been overlooked or dealt with in a superficial manner.

Two problems that had to be faced were that the original publishers, due to circumstances beyond their control, were unable to publish a new edition along the lines of the first, and that George Ray, for personal reasons, felt unable to co-operate fully in the new venture.

Happily, the Macmillan Press, with the agreement of Kimptons, decided to publish a second edition, and George Ray kindly offered to rewrite completely his chapter on the occlusion.

As a result the remainder of the book has been revised by me and I accept full responsibility for any omissions or errors. That is not to say that I have altered everything. The format remains virtually as before, having been favourably received by many students and practitioners who have expressed their views to me.

George Ray has rewritten Chapter 2, on the occlusion, bringing to this difficult subject a breath of commonsense, which should help students of all ages to comprehend the fundamentals of what has become over-complicated through an excess of misplaced zeal and theorisation. It was Leonardo da Vinci who advocated simplicity as the basic tenet of scientific investigation and mechanical development. It is still true today in many spheres of activity, not the least of which is dentistry.

In Chapter 3, the section on pulp capping has been enlarged, while the chapter dealing with physical considerations has been removed, although certain highly relevant aspects have been included in the chapter on restoration form. A new section on the physical considerations of castings and investments is now included at the end of the chapter on impression techniques.

Four-handed dentistry, now an accepted and widely practised procedure, is dealt with in Chapter 7 .

Calcium hydroxide cements, liners and high copper alloys are covered and, thanks to the Editor of the British Dental Journal, the excellent guidelines for handling mercury, prepared by Professor G.S. Nixon and Dr Christine Helsby, have been reproduced.

Composite resins and the acid etching technique have been brought up to date, but many of the older techniques have been eliminated or modified, whilst the glass ionomer cements, which are of fairly recent origin, are described.

The section on porcelain contains reference to the bonded alumina crown, and pin-retention for plastic materials has been dealt with more critically than in the first edition. The latest types of pin have been described and illustrated.

Impression materials, such as the putty and wash silicones, the polyethers and the new addition-curing silicones are covered and there is a summary of factors which influence the success or failure of impression procedures. Methods for detecting the reasons why a cast restoration fails to seat are described.

The chapter on advanced restorative dentistry has been enlarged by the addition of 'Diagnosis and Treatment Planning', and operative procedures are described in greater detail. Some attention has been devoted to the problems of fractured facings and the removal of crowns and bridges.

There is a section, in the chapter on the threequarter crown, dealing with alternative types and modifications, in which the techniques for preparation are described.

The pin-ledge preparation is unjustly neglected and frequently ill-prepared. However, space has been 
devoted to the indications for its use and the method for its preparation and impression-taking.

The chapter on post crown preparation has been augmented by adding the technique for constructing a cobalt-chromium wrought post and building a core pattern in acrylic resin burn-out material in the mouth.

Finally, the greatest increase in factual content has gone into the chapter on Endodontics, related especially to the use of calcium hydroxide as a canal medicament, the treatment of the 'Endo-Perio' lesions and the author's own solutions to a number of endodontic problems.

Throughout the book, numerous research papers have been quoted and there has been a great increase in the number of references. This relates to the greater awareness among teachers that the student or dental surgeon must spend a good part of his time finding out the latest developments in thought, materials and techniques by reading current literature.

There have also been changes in many of the photographs and illustrations, and helpful criticisms of the first edition have been of inestimable value in preparing the manuscript.

I would like to express my thanks to Charles Day for his help with the photography; to Marcus Woods for a few of the illustrations; to Suzanne Messing for typing the manuscript; and to my wife for putting up with the long anti-social evenings while I struggled with what turned out to be a more difficult task than the first edition. 